\title{
Impact of Fiscal Deficit on Inflation in Sri Lanka: An Econometric Time Series Analysis
}

\author{
A.L.Mohamed Aslam ${ }^{1, a^{*}}$ and S.M. Ahamed Lebbe ${ }^{2, b}$ \\ ${ }^{1}$ Sri Lanka Planning Service, Ministry of National Policy Planning, Sri Lanka \\ ${ }^{2}$ Senior Lecturer in Economics, South Eastern University of Sri Lanka \\ aEmail: mohamedaslamalm@gmail.com, ${ }^{\mathrm{b}}$ Email: smahamed08@gmail.com
}

\begin{abstract}
Keywords: Fiscal deficit, Inflation, Multiple Regression, Time Series Data, Government Revenue and Expenditure
\end{abstract}

\begin{abstract}
There is a relationship between the fiscal deficit and inflation, which was confirmed empirically in several studies conducted in many countries. Sri Lanka has been encountering the problem of inflation for the recent years. But in Sri Lanka, this proposition has not yet been studied scientifically. Therefore, this study was going to fill this gap. The objective of this study was to test the impact of fiscal deficit on inflation in Sri Lanka. For this study, the annual time series data were used during the period of 1959 to 2013. The fiscal deficit, exchange rate, government expenditures and import outflow were used as independent variables while the Colombo consumer price index was considered as dependent variable which was proxy variable for inflation of Sri Lanka. In addition, the multiple regressions model was used to test the impact of fiscal deficit on inflation. Based on the regression results, the fiscal deficit preserved the positive relationship with inflation in Sri Lanka at one percent significant level. Therefore, this study confirmed that the fiscal deficit accelerates the inflation in Sri Lanka.
\end{abstract}

\section{Introduction}

Fiscal deficit is an important issue in developing countries which usually impacts on following macro economic variables: economic growth, interest rate, inflation, etc. The impact of fiscal deficit on macroeconomic variables was studied by Keynesians and Monetarists. The Keynesian argues that the fiscal deficit influences on interest rate, private investment, and inflation. In the meantime, the Monetarists also accept that the fiscal deficit manipulates on money supply and inflation. Both of them agree that the fiscal deficit impacts on the countries' inflation. In this context, the fiscal deficit means the negative balance of budget which conducts with inflation in financing methods of the deficits $[1-4]$.

In Sri Lankan experience the fiscal deficit recorded by 10.2 percent on the gross domestic product in 2001 which decreased by 5.9 percent in 2013. In 2014, the government tried to reduce the fiscal deficit by 5.5 percent but it has failed because the fiscal deficit unexpectedly increased by 6 percent. In the meantime, the Sri Lankan government expects to reduce the fiscal deficit by 5.9 percent in $2016[5]$.

Inflation means the increasing the price level of countries which usually measures using price index. In Sri Lanka, to measure the inflation the Colombo Consumer Price Index (CCPI) is used. According to the Central Bank report in 1995, the inflation recorded (-0.89) which increased by $22.8 \%$ in 2008. As average it was recorded 9.89 percent from 1986 to 2015. But, the monetary authorities continuously try to limit the inflation into odd numbers [5].

Globally, there is number of studies on the nexus between the fiscal deficit and inflation using empirical data which got mixed results from their studies. Some of them found the positive relationship between the fiscal deficit and inflation. Others confirmed that there is no relationship between the fiscal deficit and inflation. But, this relationship in Sri Lankan context was not econometrically studied therefore, this situation arises a gap in this field. So, to fill this gap this study is designed as introduction, objective, literature review, research methods, results, and conclusion. 


\section{Objective}

The objective of this study is to test the impact of fiscal deficit on inflation in Sri Lanka during the period of 1959 to 2013.

\section{Literature review}

In this research the following previous studies conducting the relationship between the fiscal deficit and inflation consider as literature reviews of this study:

[9] studied the impact of budget deficit on inflation in Tanzania. In this study the annual time series data were used and the multiple regressions model was employed to test the objective. Finally, this study concluded that the budget deficit positively and significantly impacted on the inflation of Tanzania. While [1] tested the same objective using the Iranian data during the period of 1960 to 1999 which study used Auto Regressive Distributed Lag (ARDL) bound testing approach to test the cointegration between the variables. This study found that the budget deficit accelerated the inflation in Iran during the study period. In the meantime, [8] investigated the impact of budget deficit on inflation in Zimbabwe using the time series data during the period of 1980 to 2005. This study concluded that the budget deficit speeded up the high inflation in Zimbabwe during the sample periods. [6] examined the relationship between the budget deficit and inflation in Colombia, which study summarized that the budget deficit had a the long - run relationship on the inflation during the study period. Meanwhile [11] studied the relationship between the budget deficit and inflation in American experience using the annual time series data from the period of 1974 to 1980. In this study the econometric Vector Auto Regressive (VAR) model was used to test this relationship. Finally, this study concluded that there was no relationship between budget deficit and inflation in America during the sample periods. [7] studied the relationship among the budget deficit and inflation in 17 developing countries from 1960 to 1985. For testing this relationship the Vector Auto Regressive (VAR) method was used. At last this study explored that the budget deficit did not impact on inflation in the selected countries. [2] tested the impact of budget deficit on inflation and economic growth of selected ten industrializes countries. To test this impact, this study used the annual time series data from the period of 1952 to 1983 and considered the regression method using Ordinary Least Squared (OLS) techniques. This study concluded that the budget deficit impacted on the economic growth of selected countries, but did not impact on the inflation of these countries.

Whole literatures in this study used different methodologies to get the results and got mixed results. As mentioned in the introduction, some literatures indicted that the budget deficit positively impacted on inflation. But others pointed out that the budget deficit did not impact on inflation.

\section{Research methods}

In this study the inflation rate of Sri Lanka was considered as dependent variable which was substituted by the Colombo Consumer Price Index (CCPI). The fiscal deficit was the key independent variable and other three variables: Exchange Rate, Government Expenditure and Imports Outflow were used as control independent variables.

In this study the annual time series data were used during the period of 1959 to 2013 which were gathered from the Central Bank reports of Sri Lanka. To test the impact of fiscal deficit on inflation, the multiple regression equation was utilized. The relationship between dependent variable (Inflation) and independent variables (inflation; exchange rate; government expenditure and import outflow) is shown by mathematical function which shows bellow:

$$
C C P I_{t}=f\left(F D_{t}, E R_{t}, G E_{t}, I P_{t}\right)
$$

When this mathematical function (1) was extended as regressions model, the extended model was as follows:

$$
C C P I_{t}=\beta_{0}+\beta_{1} F D_{t}+\beta_{2} E R_{t}+\beta_{3} G E_{t}+\beta_{4} I P_{t}+U_{t}
$$


Where: $C C P I_{t}$ : Colombo Consumer Price Index, $F D_{t}$ : Fiscal deficit, $E R_{t}$ : Exchange rate, $G E_{t}$ : Government expenditure $>I P_{t}$ : Import outflow $>U_{t}$ : Error term

In this study, four types of regression models were considered such as linear, log- linear, linear $\log$, double $\log$ models. These constructed based on the equation (2). Then, to test the stability of whole models in this study, the CUSUM - residual test was employed. In addition the R- squared Fstatistic and Durbin Watson test statistics of total models were considered to confirm of validity of models. After that, the Breusch - Godfrey serial correlation LM test was used to identify the serial correlation effect of those models. From the all testing, the linear regression model was selected to interpret the outcomes. To explain the impact of fiscal deficit on the inflation, the sign of coefficient, t- statistic and probability value of each variable were deeply considered.

\section{Results}

As mentioned in the research method, the following regression models fitted to test the impact of fiscal deficit on inflation in Sri Lanka. Table - 1 illustrates the $\mathrm{R}$ - squared, F- statistic and Durbin Watson statistic of entire models in this study and table -2 demonstrates the Breusch - Godfrey serial correlation test results of mentioned models. Finally the each CUSUM diagram individually explains the validity of the model.

Table 1. Basic statistics of entire model

\begin{tabular}{|c|c|c|c|}
\hline Models & $\begin{array}{c}\text { R- } \\
\text { squared }\end{array}$ & $\begin{array}{c}\text { F- } \\
\text { statistic }\end{array}$ & $\begin{array}{c}\text { Durbin } \\
\text { Watson value }\end{array}$ \\
\hline Linear model & 0.8066 & 52.11278 & 1.5504 \\
\hline Linear- log model & 0.7612 & 30.28336 & 0.1852 \\
\hline Log- linear model & 0.7269 & 158.6592 & 1.9798 \\
\hline Double log model & 0.9727 & 343.1713 & 0.2542 \\
\hline
\end{tabular}

Source: Estimated from secondary data

Table 2. The results of serial correlation test

\begin{tabular}{|c|c|c|c|c|}
\hline $\begin{array}{c}\text { Estimated } \\
\text { models }\end{array}$ & $\begin{array}{c}\text { F- } \\
\text { statistic }\end{array}$ & $\begin{array}{c}\mathrm{p}- \\
\text { value }\end{array}$ & R-squared & $\begin{array}{c}\mathrm{p}- \\
\text { value }\end{array}$ \\
\hline Linear & 1.401511 & 0.2561 & 3.034587 & 0.2193 \\
\hline Log- Linear & 0.577261 & 0.5652 & 1.291818 & 0.5241 \\
\hline Linear- Log & 358.2911 & 0.0000 & 40.94308 & 0.0000 \\
\hline Double Log & 85.52709 & 0.0000 & 35.27871 & 0.0000 \\
\hline
\end{tabular}

Source: Estimated from secondary data

According to the table 1 and 2, this study considers the linear regression model to interpret the outcomes of this study because this model is satisfied all statistical recruitments of model selection criteria. Therefore, this study recommends the linear regressions model to demonstrate the outcomes of this study. 
The CUSUM test in this study is used to confirm the validity of whole models. The following group of figures shows the CUSUM diagram of the each model:

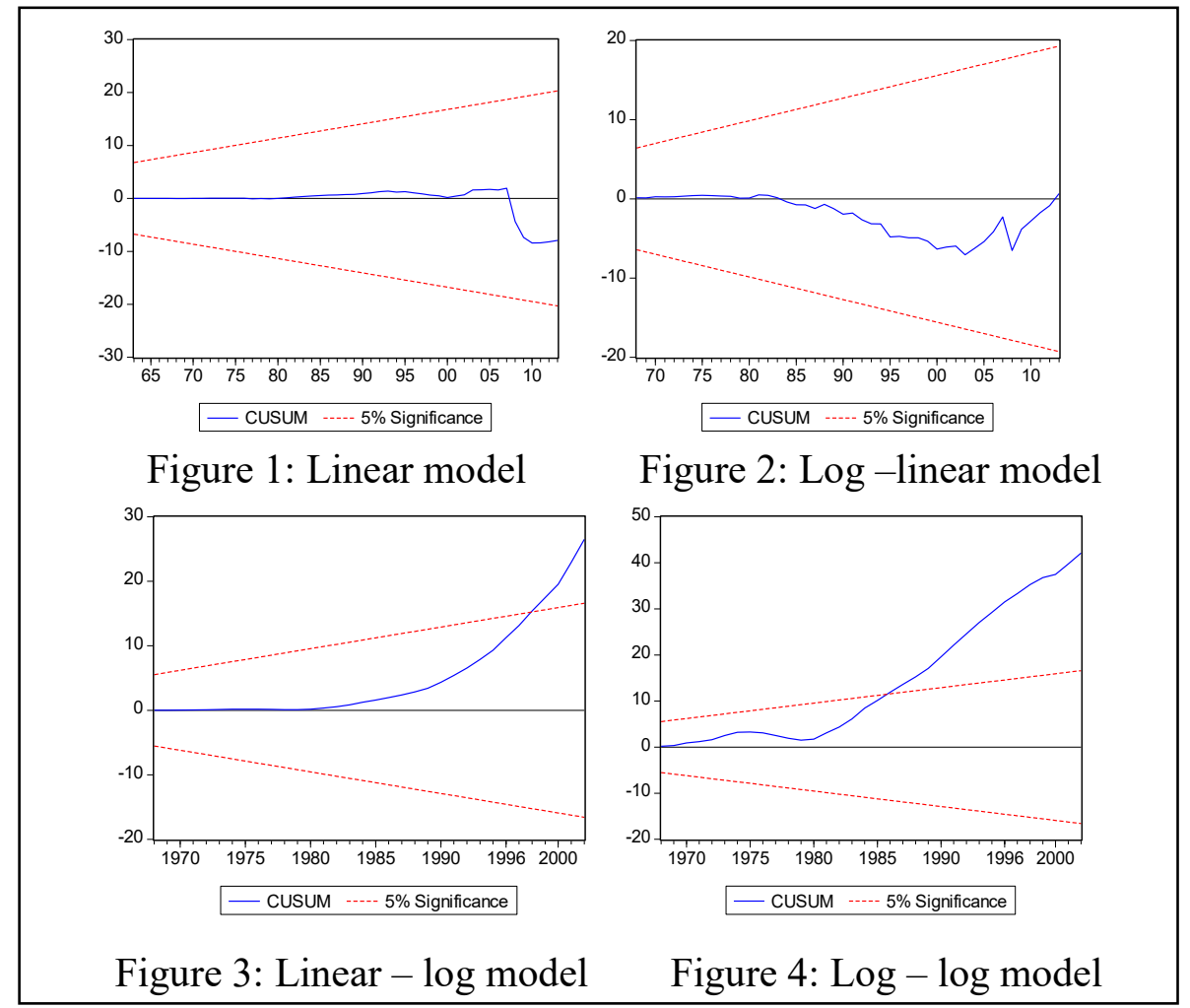

Source: E- views software

Figure 1. Group of CUSUM figures for each model

In this study the CUSUM diagram also confirms that the linear regression model is stable model. Because, the CUSUM line for the linear model cycles among the CUSUM grid lines at 5\% significant level, so the linear model is considered to explain the outcome of this study. The following table shows the outcomes of the linear regression model.

Table 3. The regression results of linear model

\begin{tabular}{|c|c|c|c|c|}
\hline \multicolumn{5}{|c|}{$C C P I_{t}=-0.068-8.86 E R_{t}+61.97 F D_{t}-1.14 G E_{t}-0.101 I M P_{t}$} \\
\hline Variables & Coefficient & Std.Error & t- statistic & P-value \\
\hline C & -0.068 & 0.02 & -3.022328 & $0.0039^{*}$ \\
\hline ER & -8.86 & 1.52 & -5.816993 & $0.0000^{*}$ \\
\hline FD & 61.97 & 6.471 & 9.575813 & $0.0000^{*}$ \\
\hline GE & -1.14 & 4.24 & -2.685139 & $0.0000^{*}$ \\
\hline IMP & -0.101552 & 0.074508 & -1.362977 & $0.1790^{\text {ns }}$ \\
\hline R- squared: & 0.806540 & D.W: 1.550447 & F-statistic: 52.11278 \\
\hline
\end{tabular}

Source: Estimated from secondary data

In the table -3 , the $\mathrm{R}$ - squared is as 0.80 which means the independent variables of this model jointly explain 80 percent variation on the dependent variable. Therefore, this model is fitted very well because the R-squared of this model is more than 50 percent.

The fiscal deficit in the table -3 positively and significantly impacts on the inflation of Sri Lanka during the study periods. In this model, the coefficient of fiscal deficit is $61.97(0.0000)$ this demonstrates when the fiscal deficit changes by one unit, the inflation changes by 61.97 units. The fiscal deficit and inflation have same direction. 
In the meantime, the controlled variables have negative relationship on the inflation of Sri Lanka. The exchange rate maintains the negative relationship on inflation of Sri Lanka at 1\% significant level. The coefficient of exchange rate in this model is (-8.86) which indicates, if the exchange rate increases by one unit, the inflation decreases by 8.86 units. On the other hand if the exchange rate decreases by one unit, the inflation increases by 8.86 units.

As well, the regression of this study point out that the government expenditure in Sri Lanka has maintained inverse relationship on the inflation. The coefficient of government expenditure is $(-1.14)$ at $1 \%$ significant level which means if the government expenditure increases by 1 unit, the inflation degreases by 1.14 units. On the other hand if the government expenditure decreases by 1 unit the inflation in Sri Lanka increases by 1.14 units.

\section{Conclusion}

The objective of this study was to test the impact of fiscal deficit on the inflation of Sri Lanka by using annual time series data for the period of 1959 to 2013. To investigate this impact, fiscal deficit, exchange rate, government expenditure and import outflow in this study were considered as independent variables, in the meantime inflation of Sri Lanka in this study was employed as dependent variable. And also, the multiple regressions model was used to explain the impact of fiscal deficit on the inflation of Sri Lanka.

According to the outcomes of the multiple regressions, this study found that the fiscal deficit positively and significantly impacted on the inflation of Sri Lanka. Therefore, this study concludes that the increasing fiscal deficit of Sri Lanka accelerates the inflation of Sri Lanka. Economically, this is not acceptable situation. Therefore, to regularize this situation this study recommends the following suggestions.

$>$ Fiscal policy makers of Sri Lanka do not have to consider the banking sector for financing the fiscal deficit (Example: the Central Bank of Sri Lanka and the Commercial Banks)

$>$ Non creditable sectors can be used (Example: National Saving Bank, Insurance Cooperation, Employs Trust Fund, Cooperative Savings, and Departmental Collection)

$>$ Non marketable sectors: Widows and Orphanage Funds, Treasury Deposits can be utilized to financing the fiscal deficits

$>$ Government of Sri Lanka has to attempt to get the foreign aid to fill the fiscal deficit.

\section{References}

[1] A. Alavirad, S. Athawale, The impact of the budget deficit on inflation in the Islamic Republic of Iran, Organization of the petroleum Exporting Countries (OPEC) Review, (2005).

[2] A.A. Protopapadakis, J.J. Siegel, Are Money Growth and Inflation Related to Government Deficit: Evidence from Ten Industrialized Economies, Journal of International Money and Finance. 6 (1987) 31-48.

[3] A. L. Mohamed Aslam, Impact of Money Supply on Sri Lankan Economy: An Econometric Analysis, International Letters of Social and Humanistic Sciences. 67 (2016) 11-17.

[4] A. L. Mohamed Aslam, Tax Revenue and Government Expenditure in Sri Lanka: an Econometric AEG Testing Approach, International Letters of Social and Humanistic Sciences. 66(2016) 31-37.

[5] Central Bank Annual report Central Banka of Sri Lanka, Colombo, 2014.

[6] I. Lonzano, Budget deficit, money growth and inflation: evidence from the Colombia case, Journal of Barradores de Economica. 537 (2008). 
[7] J.D. Haan, D. Zelhorst, The impact of government deficit on money growth in developing countries, Journal of International Money and Finance. 9 (1990) 455-469.

[8] M. Albert, The impact of a budget deficit on inflation in Zimbabwe, Munich Personal Re PEc Archive. 24227 (2008).

[9] M. Solomon, W.A. De Wet, The effect of budget deficit on inflation: the case of Tanzania, South Africa Journal of Economic and Management. 7:1 (2004) 100-116.

[10] O.C. Akcay, C.E. Alper, S Ozmucur, Budget deficit, money supply and inflation: Evidence from low and high frequency data for Turkey, Department of Economics, Bogazici Universit, 1996.

[11] S.W. Barnhart, A.F Darrart, Federal deficit and money growth in United States, Journal of Banking and Financing. 13 (1989) 137-149. 